\title{
Sustainable Policy Options for Funding Capacity Building of Teachers for the Achievement of Education 2030 in Nigeria
}

\author{
Azuka Benard Festus (Ph.D) Utalor Kate Ifeoma Okwuoza Sylvester Orobosa \\ Onuma. Obiageli Nancy \\ National Mathematical Centre, Abuja, Nigeria
}

\begin{abstract}
The focus of this paper is on the need for capacity building of teachers in Nigerian educational system and the possible policy options for funding capacity building of teachers for the achievement of Education 2030. Teachers form the hub of any educational system and no educational system can rise above the level of the teachers. The capacity of teachers needs to be upgraded from time to time in order for them to be able to adapt to the changing waves of knowledge in the education sector and the society at large. Capacity building is one of the veritable tools for updating the skills and competencies of teachers in any educational system. But this is usually affected by low fund provided for this all important activity in Nigeria. Hence, there is need for sustainable policy options to address this problem. Some sustainable policy options for funding capacity building of teachers include establishment of School Teachers' Trust Fund, annual budgeting for capacity building of teachers, Teacher Capacity Development Tax, Use of Social Development Goals Fund, and utilization of part of the Petroleum Technology Development Fund for capacity building of teachers. These would ensure steady provision of funds for the capacity building of teacher for the achievement of education 2030 .
\end{abstract}

DOI: $10.7176 / \mathrm{JESD} / 10-4-07$

\section{Introduction}

Every individual needs education on order to live effectively and efficiently in any society. In other words, education makes an individual fit to live and fit to live within any society. Without education the children cannot be well prepared to take upon their functional roles in the society such as contributing to the social, political, economic and technological development of any nation (Azuka \& Kurumeh, 2015). An educated society is much easier to mobilize, engage and orientate in pursuit of a common cause; an educated society makes it easier to foster shared values; it also engenders social cohesion and facilitates inclusive political environment, which leads to effective governance through informed and well received social contract between the government and the governed (Utomi, 2014). In realization of the fact that education is a veritable tool for achieving the objectives as a nation, the Federal Republic of Nigeria stipulated in her National Policy on Education (2008) that education is to bring about the acquisition of appropriate skills and the development of mental, physical and social abilities and competencies as equipment for individual to live and contribute the development of the society. Education is rightly recognized as 'an instrument per excellence"' for affecting national development. For Education to contribute effectively to the development of any nation, the citizen must have access to quality education. This accounts for the reason why most nations spend a great percentage of their annual budget on the Education Sector.

Among all the stakeholders in the education process, the role of the teacher appear most prominent. Hence, the popular saying that no educational system can arise above its teachers; and that no nation can rise above its schools. Consequently, no nation can rise above its teachers. It is said that education is the key that unlocks the door to modernization, but it is the teacher who holds the key to the door. The teacher is, in fact, the hub of any educational system and the determinant of educational quality. This is because in the final analysis, it is the teacher who translates educational policies into practice and programmes into action (Ukeje, 1996).

Generally, students' success in education affects the nation's economic growth and security. Investing to raise education outcomes increase the Gross Domestic Product of a nation. Teacher quality is the most important variable affecting education outcomes that the school can control. Teacher quality has greater influence on student's achievement than class size, Naira spent per student or quality textbooks and materials. For Nigeria to succeed in the global market, it must attract teachers to take up the profession and support them once they are there as being done in other countries such as Australia, Denmark, England and Scotland, Japan, the Netherland, Portugal, Finland and Greece. These countries have increased the salaries of their teachers to keep them on the job (Azuka \& Kurumeh, 2015).

In Nigeria, teachers are prepared by Colleges of Education and the Universities leading to the award of Nigerian Certificate in Education (NCE), Bachelor Degree in Education (B. Ed) and other higher degrees in Education. In the past, we had the teacher training colleges preparing primary school teachers which have now been phased out with the introduction of NCE as the minimum qualification for teaching in Nigeria (FGN 2008). Some prospective teachers acquire their certificates through part time studies while some do so through full time studies in our tertiary institutions. This may have given rise to the problem of quality of our teachers in schools.

The preparation of teachers is expected to cover the study of the subject matter, the Principles and Practices 
of teaching, Psychology, Sociology, Philosophy, Measurement and Evaluation in education (Ukeje, 2002). But it has been observed that many of Nigerian teachers lack the required qualities for effective teaching. Many of them lack the knowledge of the subject matter and the pedagogy for effective teaching. Hence, there is the need for the capacity building of teachers to improve their efficiency and productivity in the classroom. An effective teacher is expected to have knowledge of the subject matter, understand the child, and be able to inspire the child to learn new concepts in any subject area. In any teacher preparation program, teachers clearly cannot learn all they need to know in a subject area what they will teach, how students learn, and how to teach effectively. Consequently, teacher education should be seen as a professional continuum, a career- long process. Hence, teachers need a basis for ongoing learning. They need to be able to adapt to new curriculum frameworks, new materials, advances in technology, and advances in research on student thinking and teaching practice.

Many teachers lack the methodology and knowledge of subject matter to effectively teach in the school system. There is a consensus that the performance of teachers is inextricably linked to educational outcomes for both teachers and students (Egbo, 2011). Also, high quality teaching can make a significant difference in students learning and high quality teaching requires a high quality teacher workforce (Anwuka, 2017). Many teachers find difficulties in teaching some topics in schools. For instance, a needs assessment conducted by Federal Ministry of Education (2012) revealed that Mathematics teachers in Nigeria at the Secondary School level have difficulties in teaching the following topics: Word problems leading to Quadratic equations, Circle Geometry, Inequalities, Latitude and Longitude, Bearing and Distance, Permutation and Combination, Inequality graphs, Logic, Calculus, Plane and solid shapes, set Theory and probability. This implies that teachers' knowledge must be updated to improve their teaching competencies. This is the reason why capacity building workshops need to be organized for teachers from time to time. Provision of appropriate training or retraining for teachers and provision of necessary teaching resources are necessary to improve teachers' skills, knowledge base and competencies (Adebayo \& Sagaya, 2015)

Capacity building could be defined planned as actions and activities designed to help participants to develop their knowledge, skills, understanding and attitude towards improving their outputs in their work place. Chukwu (2009) defined capacity building as skills developments and knowledge needed by groups in order to participate fully in the labour market. Capacity building in education is important both for the effective functioning of the educational system as well as the other sectors of the economy. Most of the other sectors in the society rely upon a well-functioning national education system in order to develop and improve their own capacity. Capacity building has significant impact on the teacher, learners and on the success of educational reforms. Capacity building of teachers enables them to offer students the learning opportunities that will prepare them to meet world class standards in a given content area and successfully assume adult responsibilities for citizenship and work (Osuji, 2014). It should also empower individual teacher and community of educators to make complex decisions, identify and solve problems, to connect theory, practice and student outcomes (Chukwu, 2009).

Capacity building workshops help to improve teachers' knowledge of subject matter and pedagogy of teaching in schools. For instance, a study was carried out to determine the effect of capacity building workshop on the Federal Unity College teachers' knowledge of mathematics subject matter in Nigeria. The results of the study revealed that there was a significant difference in the pre- test mean and post -test mean mathematics knowledge scores of teachers exposed to capacity building workshop. Also, there was no significant difference in the mean mathematics knowledge scores of low ability, medium ability, and high ability teachers exposed to capacity building workshop. The study concluded that capacity building workshop improves the teachers' knowledge of Mathematics subject matter irrespective of their sex and ability levels. It therefore recommended that capacity building workshops should be organized for all teachers at regular intervals (Azuka, Ajie, Oluwaniyi, Ojo \& Durojaiye, 2017). Similarly, a report of the workshop for mathematics teachers of Federal Unity Colleges held at Enugu in 2018 indicated that the test mean score of the teachers rose from pre-test mean score 42.08 to post- test mean score of 75.4 showing an increase mean score of 33.36. Thus, the workshop had impressive positive effects on the knowledge of the subject matter of mathematics topics of the teachers (Azuka, \& Ajie, 2018).

In general, capacity building of teachers has positive impact in their performance in the classroom. There is a dare need for the continuous retraining of teachers through capacity building workshops. But the quantity and quality of capacity building workshops are usually affected by scarcity of funds and low budgetary provisions for this purpose. A visit to some schools in Nigeria reveals that some teachers have never attended any capacity workshop for over ten years of their engagement in the job of teaching. This is definitely very counterproductive and would affect the quality of their outputs in the school system. The main consequence is the low quality of school graduates and their inability to perform well at work place and in the society. When students are not well prepared in the school, they resort to cultism, crime and examination malpractices in the society. This calls for the need for recommendations for sustainable policy options for funding capacity building of teachers in our society.

Teachers are very important in any society. In 1958 after the Russian sputnik in 1957, the Professors of Education in USA, conscious of the Central importance of the teachers and teacher education in social change and national development, organized a historic Conference on Teacher Education in the State of Ohio. The theme of 
the conference was 'the Education and the Teacher', One Professor Jack Allen in his Memorable and historic address to the conference entitled "Always there stands the teacher'" declared:

One of the Prime functions of the school, indeed the chief function, is to provide a setting within which boys and girls can grow intellectually; this can only be accomplished through the learners association with information, knowledge and facts. Books can help, so can laboratories. So can numerous other types of learning materials. But always there stands the teacher, always on the stage, often in front or center. What he knows can make a difference. What he does not know can be an irreparable loss.

Another speaker at the Conference, Professor Randale M. Whale of the American National Academy of Science had this to say inter alia:

Without adequate number of inspiring, well informed teachers fully prepared to meet their responsibilities in our schools, we cannot have good education and without good education, we cannot hope for long to meet successfully the challenges of a changing world (Horderfield \& Stinnet, cited in Ukeje, 2002).

Back in Nigeria, Lassa (2005) quoted the report of the Bagauda seminar on "Quantities and Qualities in Nigerian Education" held in 1980 stated that:

.....teachers are the main determinant of quality in education. If they are apathetic, uncommitted, uninspired, lazy, if they are ignorant in their discipline and import wrong information, they are not only useless but dangerous. The kind of teacher trained and posted to the school may well determine what the next generation will be.

The point here is that Nigeria needs to attract and retain an adequate number well informed, inspiring, and dedicated positively oriented teachers to discharge adequately their responsibilities which is indispensable for national development. Therefore, some sustainable policy options must be put in place to fund the capacity of teachers in our nation. Some of recommendations are as follows:

\section{Establishment of School Teachers' Trust Fund.}

There is need for a School Teachers' Trust fund to cater for the professional development of teachers and their welfare during and after service to the Nation. The fund should be devoted to providing scholarship awards to intending teachers, professional development of teachers, incentives to serving teachers and retirement and related benefits to retired teachers. The school Teachers' Trust fund could be funded by devoting a certain percentage of the Education Tax and National budget to the fund. The School Teachers' Trust Fund should be established just like the Tertiary Education Trust Fund (TETFUND) and there should be Board of Trustees to govern the Fund and to be appointed on tenured basis. In United Kingdom, there is the Teacher Development Trust in Texas (David, 2014), and in California, there is the California State Teachers' Retirement system (Wikipedia, 2015). Many other countries are setting up school Teachers' Trust Fund for the development of teaching profession. This is as a result of the link between teachers' development and improved national outcomes. In the words of David (2014), the announcement of the establishment of Teacher Development Fund recognizes the importance of teacher development for improving the lives of people, and retaining and growing our best professionals. In Nigeria, we need to recognize the fact that effective professional development of teachers has some transformative effects on our economy.

\section{Annual Budgeting for Capacity Building of Teachers}

One of the major factors hindering capacity building of teachers at all levels is lack of fund due to inadequate budgetary provision for teachers' capacity building. There is need for a line item for teacher capacity building in our annual National budget, State budget, Local Government Budget, and Educational Institutions' budget. This would ensure uninterrupted supply of funds for the capacity building of teachers. Also, there is need to monitor the implementation of the budget to ensure compliance by all relevant bodies. From this budget, the Government would ensure that a given percentage of teachers are retrained annually.

\section{Teacher Capacity Development Tax}

Teachers at all levels produce the manpower for all sectors of the economy. This includes medical personnel, Engineers, Administrators, lawyers, Pilots, Soldiers and all other professionals. Therefore, a special tax for teacher capacity building should introduced. This tax should be collected from all private and public organizations that employ labourers including construction companies, manufacturing companies, hotels, transportation companies and other income generating companies and agencies. The tax should be graduated according to the size and income of each company or organization. An agency 
for the collection and management of the fund generated should be set up to collect and ensure proper utilization of the fund for capacity building of teachers.

\section{Use of Social Development Goals Fund.}

The Social Development Goals fund has been utilized over the years for training and provision of infrastructure in many parts of the country. It has also been used for capacity building of teachers in some cases and this has helped tremendously. Further to these, there is need for a policy to devote a part of the Social Development Goals (SDGs) fund to be directed towards the capacity building of teachers in Nigeria. The fund for this purpose should be deployed at the Federal, State, and Local government levels. This would ensure that a good percentage of teachers at the Federal, State, and Local Government levels are retrained annually.

\section{National Teacher Education Standard Fund.}

Every citizen passes through the school system before becoming whatever he/she becomes in life. Also, every citizen has children or relations who need to pass through the school system to fit in well into the society. In the education of all, the teacher is needed. When the teacher is not well prepared or equipped to carry out his /her duties the society will fail to function properly. It is the responsibility of the Government and all citizens to ensure that the children who hold the future of the nation are well educated to properly fit in and take charge of the society in future. Therefore, there is need for a National Teacher Education Standard Fund to be set up where all citizens can contribute for the capacity building of teachers who are responsible for the education of the children. This fund should be set up such that every worker in both public and private sectors contribute a certain percentage of his emolument for capacity building of teachers. With this in place, the Government would be able to fund the capacity building of teacher with much ease.

\section{Utilization of a Part of the Petroleum Technology Development Fund for Capacity Building of Teachers}

The Petroleum Technology Development Fund (PTDF) has been engaged in the development of technology including the personnel for the oil and gas industry. It is true that future engineers, technologists and other personnel needed in the oil and gas industry need to pass through the school system and are to be prepared by teachers. Therefore, there is need for a policy for the PTDF to contribute to the capacity building of the teachers annually. Under this policy, a certain percentage of the fund should be devoted to capacity building of teachers. At least, this could be used for the capacity building of mathematical science teachers in Nigeria. The PTDF could be made to work in collaboration with relevant agencies in the education industry to implement the training.

\section{Conclusion}

In the words of Nelson Mandela in Onwuchekwa (2015), 'Education is the most powerful weapon which you can use to change the world'. Teachers form the hub of the educational system at any country. The level of capacity and the condition of service of teachers determine the quality of teachers in any society and these have direct with the social, economic, political development of any nation. Therefore, teachers' capacity needs to be developed from time to time. Some of the policies suggested in this paper could be considered to ensure that there is fund for the capacity building of Nigerian teachers. These would ensure steady provision of funds for the capacity building of teacher for the achievement of education 2030.

\section{References}

Adebayo, F.A \& Sagaya, A.A.(2015. Teacher capacity building and students' academic Performance among public schools in Kwara State. British Journal of education, Society and behavioral Sciences. 12(3), 1-10

Anwukah, A.G.(2017, February). An address delivered at the flag off of the capacity building workshop for Science, Technical, Vocational, Mathematics teachers and Laboratory technicians held at FGC kaduna from 12th 18th February, 2017.

Azuka, B. \& Kurumeh, M.S.(2015). Mathematics for sustainable development: Implications to the production and retention of mathematics teachers in Nigeria. British Journal of Education, 3(1), 44-51

Azuka, B.F., Oluwaniyi, S.D., Ojo, S.G., Ajie J.I., \& Durojaiye, D.S.(2017). Effect of capacity building workshop on Nigerian mathematics Teachers' Knowledge of subject matter. The International Journal of Universal Multidisciplinary Educational Research Foundation, 2(1), 79-89

Azuka B.F. \& AJIe J.I.(2018). Unpublished Report of the workshop for capacity building of teachers for Federal Unity Colleges held at Enugu submitted to FME.

Chukwu, C. L. (2009). Capacity Building of Teachers, Challenges and Opportunities Implication for Educational sustainability. A paper presented at the University of Ibadan, Faculty of Education International Conference on Education for sustainable development (ICESD), May, 18-22

David,W.(2014). Press release: Teacher development trust welcomes Government fund for teacher professional 
development and calls for teachers' career structure. Retrieved on 26th December, 2014 from http:tdrust.org/press-release-teacher-development-trust educational system. African Education Indices 7(1) August 2014.

Egbo, B. (2011). Teacher Capacity Building and Effective teaching and learning: A Seamless Connection proceedings of the 2011 International Conference on Teaching, learning and Change (C) International Association for Teaching and Learning (IATEL) Co-published by: Human Resource Management Academic Research Society.

Federal Ministry of Education. (2012). Needs Assessment of Mathematics teachers in Nigeria.

Federal Government of Nigeria. (2008). National Policy on Education. Lagos: NERDC Press

Lassa, P.N. (2005). Production and retention of mathematical sciences teachers for Nigeria education system. In Ale S.O \& Adetula, L.O. (Eds). Reflective and intellective position papers on Mathematics education Issues. Abuja: Marvelous Mike ventures Ltd

Onwuchekwa, J.(2015). What is to be done about Nigerian education? Retrieved on October 20, 2016 from ojemie@businessdayonline.com

Osuji, C.U. (2014). Capacity building of teachers as a strategy in bridging the gap in Nigerian Educational system. African Education Indices, 7(1)

Ukeje, B. O. (1996, April). The role of colleges of education in national development: Past, Present and Future. A Convocation lecture delivered at the occasion of the $8^{\text {th }}$ Convocation of FCE Kontagora, Niger state.

Ukeje,B.O.(2002). Production and retention of mathematical sciences teachers for Nigerian educational system. In Ale S.O \& Adetula, L.O.(Eds). Reflective and intellective position papers on Mathematics education Issues. Abuja: Marvelous Mike ventures Ltd.

Utomi, P. (2014, December). Speech presented at the launch of Education Foundation Trust Fund of the Association of Esan professionals at Orient Hotel Victoria Iland Lagos.

Wikipedia (2015). California state teachers' retirement system. Retrieved on October 25, 2015 from http://.wikipedia.org/wiki/CalSTRS 